Article

\title{
The Regulation of Genetically Modified Organisms on a Local Level: Exploring the Determinants of Cultivation Bans
}

\author{
Ulrich Hartung * and Simon Schaub \\ Institute of Political Science, Heidelberg University, Bergheimer Straße 58, 69115 Heidelberg, Germany; \\ simon.schaub@ipw.uni-heidelberg.de \\ * Correspondence: ulrich.hartung@ipw.uni-heidelberg.de; Tel.: +49-6221-54-3726
}

Received: 24 August 2018; Accepted: 20 September 2018; Published: 23 September 2018

check for updates

\begin{abstract}
This study investigates municipalities' regulatory activities in the field of Genetically Modified Organisms (GMOs) for agricultural use. To explore the determinants of these activities, the case of Germany was selected as in this country, municipalities have legal possibilities to impose local GMO cultivation bans. Using data from 131 local council resolutions, the combination of qualitative and quantitative content analysis shows that, in most cases, no single factors, but a variety of factors lead to regulatory activity. The study reveals that functional motivations to prevent negative socio-economic effects or impacts on the environment or human health are decisive for municipalities' decisions to regulate. Furthermore, the results of the quantitative analysis unveil that municipalities often refer to both socio-economic reasons and risks for the environment and human health when justifying their decisions. Moreover, the results indicate that local policymakers impose popular cultivation bans to promote their own political success. Finally, the horizontal diffusion of regulations between municipalities, but also vertical diffusion from higher political levels can be observed. Overall, the results of this study on GMOs on a local level further emphasize the importance of analyzing the interdependencies between agroecosystems and socio-economic systems in their full complexity.
\end{abstract}

Keywords: genetically modified organisms; regulation; local level; agricultural practices; socio-economic issues; multi-level governance; Germany

\section{Introduction}

Farmers started planting the first genetically modified (GM) crops for commercial purposes in the mid-1990s. Since then, the cultivation of these crops has sparked controversies in almost every adopting country worldwide [1]. In the European Union (EU), much criticism centered on the agri-industrial farming practices that are often associated with GM crop cultivation, which, among others, is said to contest and endanger 'traditional' food production systems [2,3]. The deprecatory views on biotechnology in agricultural production led to regulatory activity on all levels of governance: in order to defuse the conflicts between the two contending agri-food systems, policymakers introduced more and more regulations, which were partially detrimental to farming based on genetically modified organisms (GMOs) [4-6].

Research has concentrated on GMO regulatory activities on supranational, national, and regional levels, as well as on the interdependencies between these levels [2,5,7-12]. This study complements previous research by investigating regulatory action on a level of GMO governance that has been scarcely analyzed in this regard yet: the local level.

This study is not the first one investigating local implications of the use of biotechnology in agriculture. This has been done by several studies from various disciplinary perspectives, including 
political science, sociology, and economics [13-17]. Friedrich [13], for instance, examined local conflicts that were sparked by the GMO issue in several municipalities in Germany. Her study provides detailed information on the actors involved, the various conflict actions and the (political) conflict settlement attempts. However, despite such insights, it remains to be analyzed whether municipalities introduce hard GMO regulations, and if so, why they do it. To address this research lacuna, the research question guiding this study is as follows: How can GMO regulatory activity on the local level be explained?

Basically, whether a municipality adopts a GMO regulation can be influenced by a multitude of factors. Despite the explorative nature of this study, three theoretical arguments are proposed to explain such action. First, we argue that municipalities regulate due to functional motivations of safeguarding certain valuable goods such as the environment. Second, we argue that political aspirations of local policymakers seeking credit for positive policy outputs lead to regulatory action. Third, we argue that municipalities anchor regulations in reaction to similar policy measures adopted beforehand by other units.

Germany was selected for this study, as in this EU member state municipalities possess legal means to prohibit GMO cultivation in their regions. More precisely, German municipalities can commit themselves to forbid farmers to plant GM crops on their leased agricultural land (self-regulation). To accomplish this, a city or commune must include a specific clause in its lease contracts for agricultural land, which then explicitly prohibits cultivating GM crops on the commune's land. To include this clause, a municipality must enact a corresponding resolution in its local council, the main legislative body of a commune representing its local citizens. The GMO cultivation ban does not need renewal and it can only be abolished by a new resolution [18].

The study reveals that various factors drive GMO regulatory activity on the local level. First, municipalities regulate due to functional motivations stemming from socio-economic concerns or perceived risks for the environment or human health. Second, they regulate due to political aspirations of local policymakers, who use popular GMO regulations symbolically to increase their political success. Third, municipalities take regulatory action because of horizontal diffusion between municipalities based on learning as well as due to vertical diffusion from higher political levels based on hierarchic coordination. Finally, the analysis of combinations of reasons for regulating GMO farming reveals, among others, that municipalities not only mention socio-economic concerns and risks for the environment or human health most frequently, but that they also do so prevalently in combination.

The remainder of this study is structured as follows. It first describes the development of the regulatory context of local GMO cultivation bans in Germany, thereby putting emphasis on regulatory activity on the EU level and the German national level. The theoretical section then focuses on three explanations for why municipalities regulate GMOs: functional motivations, political aspirations of local policymakers and policy diffusion. The subsequent section provides details on the methodology and data generation before the exploratory findings are presented and discussed in two steps. First, single frequencies of municipalities' statements are discussed and second, interdependencies between the reasons are investigated. The study ends with a summary of the main findings and some concluding remarks.

\section{The Regulatory Context}

Regulation of GMO cultivation in Germany is characterized by a complex multi-level governance structure with some regulatory flexibility on the subnational levels. Authorization of GMOs for cultivation is located at the EU level, originally covered by Council Directive 90/220/EEC and by Directive 2001/18/EC. A national safeguard clause that is included in both directives has enabled EU member states to ban cultivation of GMOs on their territory, even after their authorization. These bans had to be based on new findings on risks for human health or the environment. Only since 2015, member states may also enact cultivation bans on socio-economic or other grounds [12,19]. In Germany, the main competencies for regulating GMO cultivation are located at the federal level. Most importantly, the federal government enacted restrictive rules for governing the co-existence between conventional, 
organic, and GMO farming in 2005 [20]. In addition, it may impose nationwide cultivation bans, such as the ban on the GM maize MON810 in 2009, which de facto prohibited GMO farming in Germany as a result [21]. Despite the prohibitive regulatory framework in place at the national level, German states have used legal possibilities and imposed additional cultivation bans for GM crops on their land by including specific clauses in lease contracts [8]. Municipalities or communes are political jurisdictions located at the lowest administrative level and range from small villages to large cities. Concerning GMO cultivation, municipalities can prohibit the cultivation of GM crops on their leased land as well. German municipalities introduced GMO cultivation bans over a period of 16 years, from 1999 to 2014. A list of all municipalities can be found online in Table S1 of the Supplementary Materials. The distribution of these municipalities across Germany is illustrated in Figure 1.

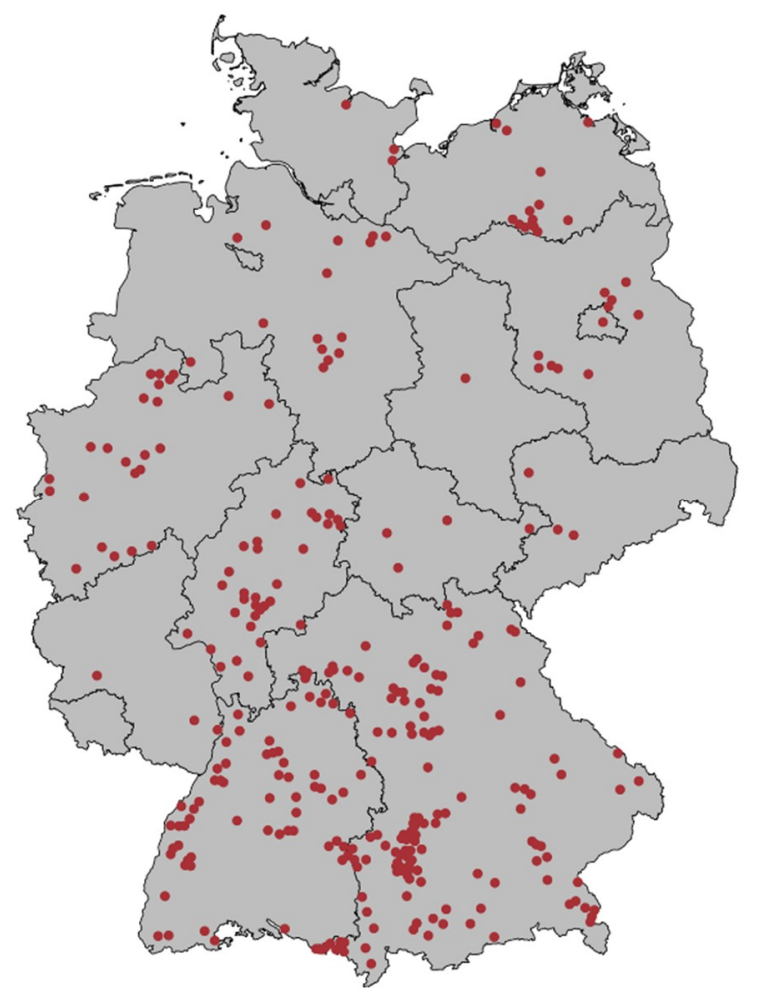

Figure 1. Municipalities with cultivation bans across Germany. Source: Own figure based on data provided by [18].

In the following, this section situates the development of municipalities' regulatory activity in its overall regulatory context. When considering this context, the development of regulatory practice on the local level can be divided into four phases.

The first phase refers to the years of the EU 'moratorium' from 1999 to 2004 . The second phase comprises the years of strictly regulated GMO cultivation in Germany from 2005 to 2008. The third phase relates to the period after the national cultivation ban on MON810 from 2009 to 2014. Finally, the fourth phase is about the years after Germany made use of a new legal opportunity, and, by way of precaution, banned all GM crops pending approval on EU level. This phase covers the years from 2015 to 2017.

To make this clear, this section only situates the regulatory activity of German municipalities within the development of the overall regulatory context. It does not attempt to analyze the possible causal effects of changes in the regulatory context on the adoption of local GMO cultivation bans. Whether a municipality takes such action can be influenced by several factors, which will be analyzed and discussed in Section 5.

Phase 1: The 'moratorium' years, 1999-2004 
The initial set-up of the EU regulatory framework on GMOs dates to 1990 when the European Council adopted Directive 90/220/EEC on the deliberate release of GMOs into the environment, and Directive 90/219/EEC on the contained use of GM micro-organisms. Based on this newly established framework, the EU, from 1995 to 1996, authorized several GM crops both for food use and commercial cultivation. This 'wave of authorizations' together with a 'public outcry' induced several national governments to oppose further approvals [5] (p. 3). Due to a blocking minority of only five anti-GMO member states, the Council of Environment Ministers stopped all GMO approvals for commercial purposes in June 1999. This so-called de facto 'moratorium' on all new approvals of GM crops for commercial cultivation lasted for five years until 2004 [22].

Figure 2 shows that only a few communes took regulatory action during the 'moratorium' years from 1999 to 2004. On the one hand, it is remarkable that the municipalities adopted these measures. That is to say, not a single GM crop had been cultivated for commercial purposes in Germany by 2004. Until this year, universities, other public research institutions, and companies conducted several scientific field trials, the number of these plots, however, decreased significantly since 2005 [23]. Although public and private plant research holds a long tradition in Germany, GM crops have not been planted for scientific purposes in the country since 2013. One major reason for this is that vandals, informed on the exact locations by a public GMO location register (see, phase 2 below), frequently destroyed the costly field trials [24]. Moreover, the communes, in principle, did not have to fear the possible cultivations of new GM crops on their land, as the required authorizations on the EU level were blocked by the 'moratorium' at that time.

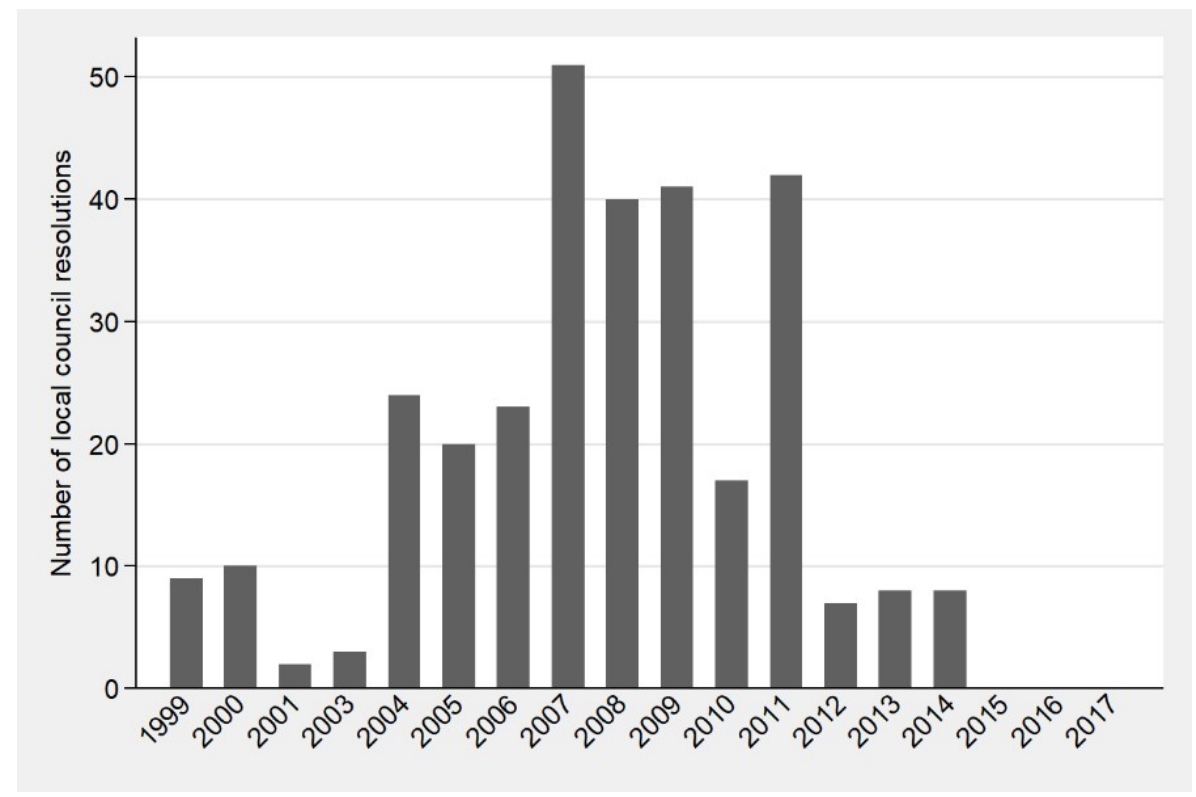

Figure 2. Number of local council resolutions, 1999-2017. Source: Based on data taken from [18].

On the other hand, the communes may have been skeptical about—or did not want to wait for-the European or the national legislator to establish regulations that prevent farmers from growing GM crops in a municipality after a possible end of the 'moratorium'. The few communes might have imposed cultivation bans instead of waiting for regulations on higher political levels. Remarkably, during the 'moratorium' years, the number of cultivation bans reached its peak in 2004. This could be due to the looming end of the 'moratorium', which local policymakers might have expected to result in possible approvals of new GM crops.

Turning back to the regulatory context in more detail, two particularly relevant processes took place during the turbulent 'moratorium' years. First, several member states provisionally banned the cultivation of specific GM crops in their territories that had been authorized for commercial cultivation 
in the EU [5] (p. 9). To achieve this, they made use of a 'safeguard clause' that was included in Article 16 of Directive 90/220/EEC [25]. According to this clause, the member states were obliged to justify national cultivation bans with new scientific evidence about risks for the environment or human health that have not yet been considered in the prior risk assessment led by the European Food Safety Authority (EFSA). The German government also made use of this legal option and imposed a cultivation ban on an EU authorized GM crop. In January 2000, Germany banned Bt176 maize (Syngenta), because of rather dubious new safety concerns [26] (p. 291). The European Commission approved this biotech crop in 1997. However, it has never been cultivated by farmers in Germany.

In a second important process during the 'moratorium' years, the European Commission replaced Directive 90/220/EEC with Directive 2001/18/EC [27], with the latter prescribing much stricter rules for the EU approval process of GM products and the cultivation of GM crops [9] (pp. 115-117). The directive obligated the member states to adopt national 'co-existence' measures, which should guarantee farmers the freedom to choose between the different agriculture production types, conventional, organic, and GMO farming. Moreover, consumers were supposed to have the 'freedom of choice' between products resulting from the different farming practices [28]. Practically, safeguarding 'co-existence' represents a highly complex task as it must secure segregation between the different agriculture production channels along the entire food production supply chain: from the seed supplier to farmers, wholesale dealers, processors, and retailers.

The EU provided guidance to the member states in establishing appropriate rules for 'co-existence' management. The European Commission published 'recommendations' for the development of national 'co-existence' measures first in 2003, and additional ones in 2010, which, however, had no obligatory character $[29,30]$. Nevertheless, the European Commission stipulated a specific approach to 'co-existence' management. This must be performed at farm-level and be based on a crop-by-crop approach; the European Commission has been criticized for these 'soft power' recommendations as being 'top-down and authoritative' [31] (p. 29). Moreover, the 'European Coexistence Bureau' provides the member states with several crop-specific guidelines to support the countries in establishing appropriate 'co-existence' measures [32].

\section{Phase 2: The years of strictly regulated GMO cultivation, 2005-2008}

In 2005, Germany implemented legally binding rules for safeguarding 'co-existence' into its national law. In the same year, farmers were allowed to cultivate GM crops on the country's territory for the first time. From 2005 to 2008, they cultivated MON810 (Monsanto), which is an insect-resistant GM maize, on increasing, but overall relatively small areas [23]. MON810 received EU approval for commercial cultivation already in 1998 and is currently the only biotech crop that is authorized for this purpose in the EU. The 'co-existence' regulations under which farmers cultivated this biotech crop in Germany for four years were extremely strict. The three most important rules are considered here, briefly: isolation distances requirements for GM crops to conventional and organic fields, the public GMO location register, and the ex-post liability rules [33]. It should be noted that these rules are complemented in German law by 'best practice' measures for GMO cultivation and detailed provisions for technical segregation [34], as well as by Regulation 1830/2003 [28] on the implementation of the EU regulation on labeling and application of GMOs.

First, German law demands minimum isolation distances for GM maize. It requires $150 \mathrm{~m}$ to adjacent conventional maize fields and $300 \mathrm{~m}$ to organic maize fields. These rules are much stricter than the seed industry advocated for, which, based on field trials on pollen drift, suggested the German government to implement $20 \mathrm{~m}$ distances from GM maize fields to conventional and organic maize fields [35] (p. 3). With its isolation distance requirements, Germany holds a midfield position among the 16 member states that have implemented such requirements. Most member states demand such large minimum distances that GM farmers are exacerbated or even de facto prohibited from cultivating GM crops. Only in Spain, the main producer of GM crops in the EU, minimum distances (20 m for GM maize) are required, thus governing, but not severely hampering, the cultivation of GM crops [36] (p. 7). 
Second, the GMO location register, in its publicly accessible part, provides information on field locations and the types of GM crops planted. In this register, farmers, as well as plant scientists, are legally obliged to disclose the exact sites where they cultivate GM crops. The register functioned as a significant barrier for both actor groups to carry out their work because the via Internet freely accessible register allows for anti-GMO activists to easily ascertain where GM crops are planted. As a result, activists occupied or destroyed many of the few GMO plantings causing pecuniary losses of both farmers and scientists [37]. The federal state Saxony-Anhalt objected the GMO location register at the German Supreme Court in 2005, which decided five years later that this rule was in line with the German Constitution [10] (p. 180).

Third, the German liability rules address the EU's requirement to enforce ex-post measures that determine who must cover the costs of possible economic damages that are caused by GM agriculture on fields where the two other farming practices are applied. According to these rules, GM farmers are strictly liable for damages caused, for instance, by the 'contamination' of non-GM crops due to pollen wafting from their GM fields. The maximum liability of GM farmers amounting to $€ 85$ million is extraordinarily high. It is remarkable that even if GM farmers have met all requirements and adjacent properties are polluted accidentally, they are not exempt from possible liability claims of conventional or organic farmers. Moreover, if GM fields are possible sources of damage, the respective GM farmers are jointly liable [20] (p. 49). Particularly, this liability regime made it an existential risk for farmers to cultivate GM crops in Germany [10] (p. 178).

Altogether, the German 'co-existence' regulations comprise strict ex-ante regulations and strict ex-post liability rules. Thus, the regulatory framework on GMOs in place in Germany is more prohibitive when compared to most other member states $[7,20]$. Together, the three policy instruments were intended to guarantee 'peaceful co-existence' in Germany. However, these rules de facto 'postponed' the conflicts over GMO cultivation from the supranational and the national level to the local level. The 'co-existence rules' allowed farmers to cultivate GM crops for commercial purposes for the first time in Germany. Subsequently, some farmers started cultivating the GM crops despite the very strict regulation in place [23]. Small-scale and organic farmers, however, perceived the incipient GMO cultivation as a threat. Together with environmental NGOs, they advocated against the idea of 'co-existence' in principle and demanded very strict 'co-existence' measures at the least. These actors considered 'co-existence' not primarily as an economic issue, but an ethical, environmental, and socio-economic one [26] (pp. 289-290). On the other hand, the German farmer union and the agribiotech industry attacked the 'co-existence' provisions in Germany for the unduly high barriers to GMO cultivation [2] (p. 183). Thereby, the rules 'intensified domestic conflicts between advocates of [the] contending agri-paradigms' [2] (p. 183).

Turning now back to Figure 2, we can see that multiple communes introduced cultivation bans in the period of strictly regulated GMO cultivation from 2005 to 2008 . The peak of the annual growth rate is in 2007 with 54 new local council resolutions. One plausible way of interpreting this high number of cultivation bans is that intensified domestic conflicts, along with the new possibility of farmers to grow GM crops on their agricultural land, motivated local policymakers to introduce these bans. Moreover, these actors could have perceived the existing 'co-existence' regulations as being insufficient and therefore seized cultivation bans additionally.

Phase 3: The years after the national cultivation ban on MON810, 2009-2014

On the grounds of the 'safeguard clause' included in Directive 2001/18/EC, the German government imposed a cultivation ban on MON810 in 2009. Thereby, the legislator stopped farmers after a period of four years from further cultivating this biotech crop. Similar as in the case of Bt176, the MON810-ban is considered as being based on scientifically questionable reasons and as being, in fact, motivated by the political considerations of the German government [38]. Several leading German and European authorities—-the Federal Office for Risk Assessment, the Julius Kühn Institute, the Robert Koch Institute, the Federal Agency for Agriculture and Forestry (since 2008), the Central 
Commission for Biosafety, and EFSA-had considered MON810 to be safe [39] (p. 275). Since the ban, the 'co-existence' rules are, in fact, rather theoretical, as no other GM maize varieties-and in general no other GM crop-is authorized for commercial cultivation in the EU.

Figure 2 shows a mixed picture for the years after the national cultivation ban on MON810. At first glance, it may surprise that the regulatory activity varies considerably between 2009, 2010, and 2011, and the subsequent years. While considering that the MON810-ban de facto prohibits commercial GMO cultivation in Germany, the relatively high number of local cultivation bans taken by the communes in 2009 seems astonishing. However, this number might be explained by the fact that corresponding council resolutions had been initiated and prepared before the federal government imposed the ban in April 2009. The strikingly low number of cultivation bans in 2010 may be interpreted as a reaction of local policymakers, who, due to the national ban, might not have seen any more need to regulate. While many municipalities adopted local cultivation bans in the period of 'co-existence' regulations from 2005 to 2008, only the national MON810-ban in 2009 appears as having satisfied the regulatory needs of the communes, as indicated by the low number in 2010 .

In addition, Figure 2 indicates that significantly more communes established cultivation bans only one year later in 2011. A probable explanation for this increase is that GM potato EH92-527-1, better known as 'Amflora' (BASF), gained authorization for commercial cultivation in 2010. After a marathon authorization procedure of 13 years, the modified starch potato was the third-and to date last-GM crop that received approval for commercial cultivation. What might have motivated the communes to impose cultivation bans in 2011 was not only the fact that this GM crop gained approval. Rather, farmers immediately started planting 'Amflora' already in the approval year, but on overall very limited areas (a total of 17 hectares, and only for two years from 2010 to 2011) [23]. The reason for the short period of cultivation was that BASF suspended the marketing of 'Amflora' in the EU when it shifted its plant biotechnology division to the United States in 2012 [40]. In addition, after a lawsuit by Hungary, the General Court of the European Union, overturned the approval of 'Amflora' in 2013 because of procedural errors that were made by the European Commission in the approval process [41] (pp. 195-199). Besides BASF, other leading agri-biotech companies-Bayer (in 2004) and KWS (in 2015) relocated their plant biotechnology divisions from Germany to the United States (US) [42].

In the years from 2012 to 2014, only a few communes took regulatory action to impose local cultivation bans (Figure 2). This limited number of local cultivation bans can be interpreted as the result of the fact that local policymakers did not have to fear that farmers could possibly cultivate biotech crops on their agricultural land due to the MON810-ban and to terminating the cultivation of 'Amflora'. Only very few communes might have feared potential new authorizations of new GM crops for commercial purposes, and therefore implemented cultivation bans.

Phase 4: The years after the national ex-ante bans on GM crops, 2015-2017

When inspecting Figure 2 again, we can see that not a single commune imposed a cultivation ban during the three-year period from 2015 to 2017. This development might be related to Directive 2015/412. This directive was adopted in March 2015 and it gives the member states the possibility to institute restrictions or bans during the approval process for a given GM product (ex-ante), and to restrict or prohibit the cultivation of specific GM crops in the aftermath of granting an authorization on the EU level (ex-post) [43]. Germany used the ex-ante option and demanded restrictions of geographical scopes of all GM crops pending approval in the authorization pipeline at EU level. It was not the only country doing so: 16 other member states and four regions made varying use of this new legal possibility [12] (p. 810). The German government reasoned the exclusion of its territory from the future authorizations of six GM maize varieties (Syngenta withdrew two varieties) with the incompatibility of GM maize with 'usual agriculture land use in Germany. It would have negative effects on the cultivation of conventional and organic maize' [44] (p. 2).

With increasing numbers of municipalities having implemented cultivation bans, the potential number of future cultivation bans automatically decreased. It seems, however, plausible to interpret the 
regulatory inaction of German communes from 2015 to 2017 as a result of the regulatory proceedings that took place at the EU level. As a reminder: in Germany, more than 11.000 communes exist, which, in principle, could adopt GMO cultivation bans. However, after the national ex-ante bans on all the GM crops pending approval, the communes might not have viewed it necessary to regulate GMOs themselves anymore. These ex-ante bans might have signaled to local policymakers that farmers, at least in the medium term, would not be given the possibility to grow GM crops in their territories.

\section{Theoretical Considerations}

What motivates municipalities to become active and pass GMO cultivation bans? Research indicated that multiple factors can explain policy-making at the local level including actor-specific factors, such as the party-affiliation of mayors or structural factors, like, for instance, the size of a commune $[45,46]$. Theorizing all the possible factors would contradict the exploratory logic of this study as well as overstretch this piece of research. Therefore, this study focuses on three arguments why municipalities might be motivated to ban the cultivation of GM crops in their territories: functional motivations, political aspirations of local policymakers, and policy diffusion.

Due to the high level of risk that is often attributed to GMOs [47], several possible functional motivations exist, which might induce local policymakers to advocate cultivation bans. At their core, these motivations are shaped by normative, cultural, religious, and other beliefs, and aim at preserving or protecting certain valuable goods inferred from these beliefs. For instance, environmentalists tend to consider GM crops as dangerous to natural biodiversity. Similarly, consumers often regard GM foods as being a potential risk to their health. Most risk assessment studies conclude that GM crops have no significant adverse effects on the environment or human health $[48,49]$. Nevertheless, local policymakers might be motivated to protect certain valuable goods, such as biodiversity or citizens' health, and therefore aim at preventing the cultivation of GM crops on communal territories.

Another important functional incitement for a local unit to impose a cultivation ban might be the preservation of conventional and organic farming. It is believed that their existence can be better secured if the area that is owned by a commune is covered by rules that prevent farmers from cultivating GM crops. Cultivation bans might be viewed a means to guarantee the labeling threshold of $0.9 \%$ set for adventitious and/or technically unavoidable GMO ingredients, which applies to conventional as well as to organic products in the EU [28,50]. This aspect is even more relevant for organic farming as many organic companies have voluntarily prescribed a more restrictive labeling threshold of $0.1 \%$ for GMO ingredients. Further monitoring measures to meet these thresholds would entail additional financial costs, particularly for organic farmers-a scenario that comes into relevance when GM crops are planted near organic cultivations [20] (p. 7).

Local policymakers might also be motivated to ban GMO cultivation due to socio-economic concerns that are related to GMO farming [51,52]. The industrial farming practices that are often associated with GMO agriculture are frequently considered to threaten traditional small-scale agriculture in rural spheres. Therefore, GMO cultivation might be considered a direct threat to small farmers, existing upstream and downstream industries, and consumers of food from traditional food-production systems [53]. However, by implementing cultivation bans, municipalities can protect and support traditional food-production systems. So, they can contribute to avoiding possible shifts in the socio-economic status triggered by GMO farming from which mainly agri-biotech companies and large-scale farmers would benefit, but actors operating in traditional agri-food systems would suffer.

Several other functional reasons that are motivated by religious, ethical, moral, or globalizationcritical beliefs might motivate policymakers to take regulatory action. When local policymakers consider certain values as not being sufficiently protected by the regulatory status quo, they may become active and try to do so themselves.

The second argument that we propose in this study is that municipalities impose cultivation bans due to political aspirations of local policymakers seeking credit for positive policy outcomes. The central objective of political parties and individual policymakers is the maximization of their vote 
share at upcoming elections as this increases their chances of becoming (re-)elected, which, in turn, allows for them to implement certain policies [54,55]. Skjæveland and colleagues [56] have shown that this idea also applies to the local level. Due to their vote-seeking aspirations, policymakers are responsive to public opinion: for the GMO case, several studies have shown that negative public opinion functioned as a major driver for several EU member states to impose national cultivation bans [57-60].

Accordingly, policymakers operating at the local level might also have strong incentives to respond to the public rejection of GMOs—or at least to distance themselves from unpopular GMO farming [61]. Hence, they might regard cultivation bans as a suitable means to increase their political success. As the GMO issue has proved to predominate several local agendas and sparked intense conflicts at this level $[13,14,62]$, the topic should attract the attention of vote-seeking local policymakers who might hope for electoral benefits from politically exploiting the issue.

The third argument refers to policy diffusion, that is, the notion that policy decisions adopted by a political unit are affected by policies that are adopted beforehand by other political units [63-66]. A key mechanism underlying policy diffusion among political units operating at the same level is learning [63] (p. 840). Learning can be understood as a process by which policymakers employ the experiences of other political units to estimate the likely consequences of policy change [65] (p. 17). According to Bednar [67] (p. 273), the chances that policies diffuse increases in constellations when other political units are characterized by similar preferences and problems and consider a certain policy at stake as 'successful'. Why should local policymakers consider a GMO cultivation ban as successful?

Drawing on the considerations above, policymakers might consider a ban that is adopted by another commune as a suitable instrument to prevent the population from environmental or health risks potentially emanating from GMOs. Moreover, these actors might consider it to be necessary to harmonize their regulations, which might foster the diffusion of these policy measures, especially among adjacent municipalities. Finally, these bans might diffuse due to the political aspirations of policymakers in recipient municipalities. If these actors observe politicians in other communes as having benefited from adopting the regulatory measure in electoral terms, this could induce them to advocate the measure with the goal of increasing their political success as well.

\section{Methodological Clarifications}

To explore the determinants of GMO regulatory action on the local level, this study employs 131 local council resolutions taken by German cities and communes from 1999 to 2017. In Germany, overall 307 communes made use of the legal possibility to include a specific clause in their lease contracts for agricultural land that forbids farmers to cultivate GM crops on communal land. As only 131 council resolutions contain relevant information on why a commune implemented these local GMO cultivation bans, the analysis of the determinants thereof will be limited to this set of communes.

Most documents inspected are freely accessible on the internet homepage http://www. gentechnikfreie-regionen.de/regionen-gemeinden/gentechnikfreie-kommunen.html. Some missing information could be found searching the internet and by contacting the municipalities. The free accessibility of the documents enables the reader of this study to check and replicate the results provided. The homepage that is cited above is operated by 'Friends of the Earth Germany' (Bund für Umwelt und Naturschutz Deutschland, BUND, Berlin, Germany) with the support of the 'Working group peasant agriculture' (Aktionsgemeinschaft bäuerliche Landwirtschaft, AbL, Hamm, Germany). The BUND advocates environmental protection issues, whereas the $\mathrm{AbL}$ aims at preserving traditional (organic and conventional) farming practices. Based on these aspirations, the two associations work closely together in advocating the strictest GMO regulations as possible. One of their lobbying strategies to accomplish this goal is their support for municipalities to ban GMO cultivation on their land.

The basic assumption underlying the use of local council resolutions is that these documents often develop from political debates between local policymakers, who are, in the first place, local 
councilors, and mayors (with or without party affiliation) representing the various interests of local citizens. Therefore, the documents can be considered as reflecting important parts of the societal and political debates in the respective municipalities. As indicated, many of the documents do not include relevant information regarding $\mathrm{w}$ cultivation bans have been introduced-instead, they only inform about whether proposals for these measures have been adopted, and sometimes on the voting behavior of the members of local councils. The varying provision of information in the council resolutions seems to be due to some formal nature of how these documents are written in the municipalities across Germany. Nevertheless, 131 documents provide multifarious information on why municipalities have imposed cultivation bans, thereby reflecting the debates that are sparked by the GMO issue in the local spheres.

From the method of document analysis, one possible limitation of this study might emerge, as it might be that this study does not encompass all the relevant reasons for regulatory action. The practical reason for this is that some arguments for banning GMO cultivation, which might have been relevant in a commune, are possibly not written down in the council resolutions, which represent our exclusive data source. For instance, mayors hoping to generate public benevolence might have implemented a cultivation ban in their communes. However, when analyzing the corresponding council resolutions, it could happen that this motive for taking regulatory action cannot be identified as no statement-implicitly or explicitly—refers to this aspect.

The study seeks to identify the drivers of GMO regulatory activity at the local level by analyzing the statements included in local council resolutions. For this undertaking, qualitative content analysis appears as the most suitable method [68]. The manual coding of the statements was started by using a coding scheme that we sketched based on the theoretical considerations. Based on an inductive procedure, we successively modified the coding scheme during the further coding process. The coding categories were revised and reduced several times until a coding scheme was derived that ensured that all the relevant empirical information contained in the documents was captured. Finally, all 131 documents were inspected again to make sure that all relevant data were included and that the assignments of the statements to the categories fulfilled the requirements of reliability.

This coding procedure resulted in various main and sub-categories, which can be inspected in Table 1 below. The five main categories the data were assigned to are the following:

Socio-economic aspects

Environmental and health risks

Imminent GMO cultivation

Local Resistance

Diffusion

The statements that were assigned to the categories provide information on how significant certain factors are for the GMO regulatory activity of German municipalities that published corresponding information. Finally, qualitative content analysis was complemented by a quantitative content analysis that looked specifically at the frequencies of combinations of sub-categories within council resolutions that were proposed by communes in order to identify patterns of reasons for prohibiting GMO cultivation at the local level. 
Table 1. Overview of the exploratory findings.

\begin{tabular}{lcc}
\hline \multicolumn{1}{c}{ Category } & Number Mentioned & Frequency Mentioned (\%) \\
\hline Socio-economic aspects & 61 & 46.56 \\
Impact on conventional agriculture & 50 & 38.17 \\
Impact on organic agriculture & 25 & 19.08 \\
Dependency on multinationals & 21 & 16.03 \\
No economic benefit & 7 & 5.34 \\
Low consumer demand & 4 & 3.05 \\
Surveillance costs & 2 & 1.53 \\
Land value conservation & 7 & 5.34 \\
Environmental and health risks & 55 & 41.98 \\
Risk for the environment & 46 & 35.11 \\
Risk for human health & 36 & 27.48 \\
Imminent GMO cultivation & 12 & 9.16 \\
Planned cultivation for scientific or commercial purposes & 5 & 3.82 \\
Potential cultivation due to new authorizations or & 9 & 6.87 \\
changes in EU rules & 44 & 33.59 \\
Local Resistance & 39 & 29.77 \\
Rejection by the population & 15 & 11.45 \\
Rejection by farmers & 42 & 32.06 \\
Character of provision & 25 & 19.08 \\
Complementary to regulations on higher levels & 7 & 5.34 \\
Preventive & 19 & 14.50 \\
Symbolic & 47 & 35.88 \\
Diffusion & 34 & 25.95 \\
Neighboring municipalities adopted identical or similar & & 12.21 \\
regulations & 16 & \\
Higher administrative units (counties) adopted identical & & \\
or similar regulations & & \\
\hline Not The & 5 & \\
\hline
\end{tabular}

Note: The numbers backgrounded grey indicate how many municipalities (or which share of municipalities respectively) mentioned any of the subcategories below. For example, 61 municipalities mentioned at least one of the seven socio-economic aspects. Source: Based on data taken from [18].

\section{Presentation and Discussion of the Empirical Findings}

Functional considerations played a key role for municipalities when introducing GMO cultivation bans; socio-economic aspects and perceived risks for the environment or human health were mentioned most often. Sixty-one municipalities justified their cultivation bans referring to socio-economic aspects, such as negative impacts on the conventional or organic agricultural sector, which amounts to about $47 \%$. Around $42 \%$ of the municipalities referred to risks for the environment or human health in their explanatory statements. Imminent GMO cultivation, either in the form of planned cultivation on a municipality's territory or due to new authorizations on the EU level, seemed to be less central, however $(9 \%)$.

Turning to political aspirations, rejection by local farmers and by the local public appear to be important aspects. Around $34 \%$ of the communes mentioned any of the two aspects of local resistance. Finally, the documents provide evidence for policy diffusion processes. About $36 \%$ of the communes referred to cultivation bans of neighboring municipalities or higher administrative units as a reason for implementing cultivation bans. Of course, cultivation bans could diffuse due to functional considerations of recipient policymakers; policy diffusion will be examined in more detail below.

\subsection{Functional Reasons for Banning GMO Cultivation}

By exploring the council resolutions, socio-economic reasons turned out to be decisive for the communes' decisions to ban GMOs. The councils mentioned the following aspects: endangerment of conventional or organic agriculture, dependency on multinationals, the absence of economic benefits, low consumer demand, surveillance costs, and conservation of land value.

Potential detrimental effects of GMO cultivation on the conventional and/or organic agricultural sector is one of the dominant reasoning in municipalities' explanatory statements. When inspecting Table 1 , which gives an overview over all statements coded, we can see that about $38 \%$ of the communes 
referred to negative effects on conventional agriculture and about $19 \%$ explicitly mentioned harmful consequences for organic farmers. Most of these communes issued serious doubts on the feasibility of coexistence in Germany. For instance, the council of Metzingen noted, 'biologists are convinced that coexistence is only feasible if bigger contiguous areas without GMO cultivation are created. However, a simple separation between GMO and GMO-free cultivation is impossible because gavelkind in Baden Württemberg led to mostly small plots of land lying closely together'. Instead of coexistence, 'inevitable creeping contamination will threaten conventional and organic farmers' livelihood'. Consequences for organic farmers resulting from contamination would be particularly severe, as they would not be able to follow the guidelines of organic farming anymore, as noted by the city council of Bamberg for instance.

Apart from the threat of contamination for conventional and organic agriculture, municipalities referred to other potential problems of GMO cultivation for local farmers. One of these issues was a possible dependency of farmers on multinationals; mentioned by $16 \%$ of the communes. The municipality Brück, for example, noted, '[the seed trading company] Märkische Kraftfutter (Märka) is the main distributor of GMOs [in Brandenburg]. Their interest lies in the use of GMOs because selling genetically modified seeds would lead to an dependency on their customers'. The council of Munich stated, 'there is a threat that increasing market concentration will make farmers and consumers dependent only on a few globally operating multinationals in a few years'. Furthermore, the council of Leipzig argued that potential future market pressures could force conventional farmers to adapt to GMO cultivation. Due to the German liability rules, 'farmers will then face a high risk of heavy claims for compensation in case of contamination or negative health impacts. Most of them would not be able to afford an appropriate liability insurance'.

In addition to the potential problems of GMO cultivation, a few municipalities cast doubts on the economic benefit of GMO cultivation and pointed to the low consumer demand for GMOs in Germany. Some municipalities also worried about potential surveillance costs resulting from measures to guarantee coexistence. Loss of land value seemed to be of some concern as well. For instance, the council of Dortmund noted, 'acreage that was contaminated by the use of genetically modified plants is limited in its usability as it cannot be used for conventional cultivation anymore. In addition, its use as compensation area is limited. Therefore, this acreage has reduced economic and ecological value'.

Interestingly, many municipalities emphasized the need to strengthen the local economy instead of preparing the ground for multinationals and called on local people to purchase local products. A councilor in Hofstetten stated, 'it is a great thing if domestic farmers are supported and people purchase products produced in the Ortenau area [the largest district in Baden-Württemberg located in the direct neighborhood to the French border]'. The council of Neufraunhofen pointed out that 'small peasant farming characterizes most parts of Bavaria. To preserve this agricultural structure, it is of particular importance to sustain and improve the living and working conditions of the population enrooted in agriculture'. Some municipalities even took the opportunity to support local farmers directly. For instance, the council of Strausberg decided that 'the use of local organic foodstuffs in cafeterias of community facilities and at public events shall be increased'. From these findings follows that the municipalities' interests in preserving existent agricultural structures and supporting their own local economy have served as a crucial reason for banning GMOs.

Regarding the second type of functional considerations, it was argued that local policymakers might consider cultivation bans as a functional means to protect the environment and human health from uncertain risks emanating from GM crops. The study shows that, to varying degrees, municipalities referred to these two potentially affected areas when justifying their cultivation bans.

Perceived risks for the environment were mentioned most often: about $35 \%$ of the communes stated that GM crops could be harmful to the environment. Most statements explicitly referred to the danger of a loss of biodiversity due to outcrossing or expanding industrialized agriculture. The council of the community Metzingen stated, 'the outcrossing of genetically modified organisms in the environment emerges as a great threat for biodiversity for years to come. Genetically modified organisms spread 
through wind and bees that transfer pollen, through humans, animals or machines that carry seeds over long distances accidentally'. The council of Dortmund further emphasized the problem of irreversibility of outcrossing by emphasizing that 'cultivation of GMOs comes with a serious intervention into [ ... ] biodiversity in the ecosystem whose consequences are difficult to foresee. However, a complex process is set in train, which can neither be stopped nor be undone, even if it turns out that the use of biotechnology was a wrong decision'. The council of Munich explicitly mentioned a possible relationship between GMO cultivation, industrialized agriculture, and the loss of biodiversity: '[the use of biotechnology] would lead to an increase in agricultural production, a further intensification of the already drastic structural change [in agriculture], [ ... ], and a loss of genetic and regional diversity'.

Risks for human health were mentioned less frequently than risks for the environment. About $27 \%$ of the municipalities referred to potential negative impacts on local people's health as a reason for banning GMO cultivation. Most municipalities referred to risks for human health in general and emphasized the problem of the uncertainty that is inherent in this risk. For instance, the local council of Hüttisheim stated, 'the main reason [for implementing GMO cultivation bans] is local citizens' health as subsequent damages of genetically modified plants are not foreseeable'.

The third set of reasons given by the communes for adopting bans relates to their fear of 'imminent GMO cultivation'. This category includes communes that perceived the likelihood that GM crops will be planted on their territories as particularly high-either due to planned cultivations on their own land or in their neighborhood or due to possible new GM crop authorizations or the liberalization of appropriate regulations at EU level. In other words, specific (anticipated) events were given as reasons for banning GMOs. Altogether, $9.1 \%$ of the communes made statements in these two regards, wherefore it seems worthwhile to investigate and differentiate the two sub-categories and analyze them in further detail.

Only a small share of $3 \%$ of all municipalities justified cultivation bans with planned cultivations of GM crops for scientific or commercial purposes in their territories or in those of neighboring municipalities. For instance, the commune of Leingarten banned GMO cultivation in response to a planned cultivation of GM maize on its territory in February 2006. Moreover, a planned release by Monsanto in another commune, Grünsfeld, led the adjacent city of Lauda-Königshofen to ban GM crops on its own territory to take a clear stance against the planned release in their neighborhood in March 2007.

As opposed to the above, the fear of GMO cultivation on municipalities' land due to new authorizations of GM crops or the liberalization of regulations at EU level seems to be more relevant (6.9\%). For instance, the council of Metzingen justified their cultivation ban in May 2004 with the end of the EU 'moratorium', because it increased the likelihood of new authorizations, and, as a result, made extensive commercial cultivation of GMOs on German acreage more likely. Likewise, the authorization of the GM potato 'Amflora' in 2010 was mentioned as a reason for the cultivation ban adopted by the city of Magdeburg in August 2010. In this case, only three weeks passed between the EU approval and a regulatory response at the local level. The new 'co-existence' rules, implemented in 2005, under which GMO cultivation was allowed in Germany for the first time, induced the community of Lahr to put the topic of biotechnology on its agenda and to eventually ban GMO farming on its territory in August 2006.

Altogether, the number of municipalities that explicitly refer to imminent GMO cultivation on their arable land is rather small. One reason for the small number of references to planned cultivations of GM crops in municipalities' explanatory statements could be the rare overall incidence of GMO farming in Germany, as pointed out in Section 2. However, this also supports our approach to investigate the multiple possible reasons in order to answer the question of what moved the other $91 \%$ of municipalities to ban GMO cultivation. 


\subsection{Policymakers' Reasons for Adopting GMO Cultivation Bans}

Some municipalities could have banned GMO cultivation due to political aspirations of local policymakers-our second theoretical explanation. According to this theoretical argument, local policymakers could attempt to increase their political success by implementing popular regulatory measures. About $33.4 \%$ of the municipalities explicitly referred to local resistance in their explanatory statements. Based on the explorative findings, one can differentiate between two actor groups: rejection by the broader local citizenship, which was mentioned by about $29.8 \%$, and rejection by local farmers, mentioned by about $11.5 \%$ of the communes.

The documents indicate that resistance by local citizens ranges between widely diffuse rejection of GMOs and concrete resistance actions, such as petitions or citizens' consultations. For instance, the community of Ainring noted in general that it shared its populations' concerns about the consequences of GMO cultivation. On the other hand, the council of Schwäbisch Gmünd specifically describes the evolution of an action alliance that collected signatures against the cultivation of GMOs in the area. Resistance by farmers is described in a similar way. Some municipalities just mentioned their farmers' general rejection of GMOs. Others described in detail how local farmers associated to gain influence or how regional farmers' federations started to intervene.

These observations indicate that some local policymakers reacted to specific forms of local resistance and to the local public opinion in general. The findings can be interpreted against the background of our theoretical reasoning according to which local policymakers might use cultivation bans for credit-claiming reasons. As already pointed out in Section 2, municipalities de facto cannot ban GMO cultivation on their territory completely. However, some still react and prohibit GM crops on municipally owned land only. If, as a matter of fact, municipalities cannot completely ban the cultivation of biotech crops on their land, why then would they still adopt corresponding council resolutions? Interestingly, some municipalities provided information on the genuine functions of their local cultivation bans, which can be differentiated into three sub-categories: complementary, preventive, and symbolic functions.

About $19 \%$ of the communes adopted cultivation bans with the aim of complementing regulations in place at higher levels - the regional and the federal level particularly. For instance, the documents from Rednitzhembach (2007) and Kammerstein (2007) state that there do not exist sufficient binding rules at higher political levels, wherefore cultivation bans should be adopted. The two communes' initiatives date back to 2007 when the national cultivation ban on MON810 had not been in place yet and the 'co-existence' rules already applied. Although the latter regulations are widely considered as being very strict, these rules appear as having disappointed municipalities as well as conventional and organic farmers, as these provisions de facto permitted farmers to cultivate GM crops.

Accordingly, the 'co-existence' rules were neither satisfactory for the anti-GMO actors nor for those farmers who wanted to grow GM crops for economic reasons (see Section 2, Phase 2). In February 2008-about one year before the introduction of the national cultivation ban on MON810-Weiler-Simmerberg was rather clear in this regard stating that 'while in countries such as Austria or Poland the state decided to become GMO-free, only in Germany bottom-up pressure would be needed'. This reinforces the argument that municipalities themselves become active and regulate if, from their point of view, sufficient regulatory measures have not been anchored on higher levels.

A few communities (about 5\%) underlined the preventive character of their council resolutions. Although none of the farmers operating in these communes cultivated GM crops or intended to do so, these municipalities decided to take precautions to assure that these crops would not be cultivated in their territories in the future. Although a local cultivation ban did not prohibit possible future GM crop plantings completely, it would send a clear message that GMO farming was not welcome in their municipalities.

About $14.5 \%$ of the communes emphasized the symbolic character of banning GMO cultivation in their areas. Instead of conceiving this provision as an actual opportunity to close a gap in current regulatory frameworks, they declared it as a political act and hoped for a signaling effect of this 
policy measure. For instance, the council of Breitenbach am Herzberg declared the commune 'as a symbolically GMO-free commune' and added, 'the political commune supports its citizens politically [... ] to prevent the establishment of biotechnology in agriculture'.

Although the proportion of municipalities that made corresponding statements in their resolutions is not particularly high, general empirical support can be found for the second theoretical explanation. Especially, the comparatively high number of municipalities mentioning local resistance in their explanatory statements indicates that local policymakers are responsive to their citizens. Apparently, local policymakers attempt to claim credit by adopting the popular ban of GMO cultivation.

\subsection{Diffusion of GMO Cultivation Bans}

Finally, we are going to deal with policy diffusion, the notion that policy decisions that are adopted by a given political unit are affected by policies adopted beforehand by other political units. Almost $36 \%$ of the communes made statements in their resolutions suggesting that diffusion somehow took place. Interestingly, the information obtained from these documents refers to two differing sources of such diffusion effects.

First, about $26 \%$ of the communes stated that they imposed cultivation bans due to regulatory action taken by other municipalities before. For example, the commune of Zell am Main banned GMO cultivation in May 2013 while referring explicitly to their neighbor community Rottendorf which had adopted the same provision three months before. Moreover, geographic proximity between municipalities does not seem to be a necessary condition for intercommunal effects. The city council of Creglingen, for example, argued against a planned field trial by Monsanto in another commune (Grünsfeld) which is about $40 \mathrm{~km}$ away. Instead, several other factors, such as personal acquaintances between local farmers, mayors, councilors, or activists might positively condition such intercommunal effects. Hence, these findings correspond with the theoretical argument of horizontal diffusion effects between municipalities. Obviously, many communes are characterized by similar preferences and problems, and therefore consider the cultivation bans that were adopted by other communes as promising, which induces them to adopt this measure, too.

Second, the documents provide evidence for diffusion effects stemming from the countylevel-and especially in those districts, where the respective county councils have declared the districts as 'GMO-free zones'. About $12.2 \%$ of the municipalities referred to decisions taken in the county councils when justifying their own provision. In some cases, the county councils, after declaring themselves as 'GMO-free', explicitly called on all communes in their district to take complementary measures and to declare themselves as free of GMOs as well. To give one example, the Bavarian commune Thurmansbang stated that 'the council of the county of Freyung-Grafenau [ ... ] adopted the basic decision to designate the district as a 'GMO-free zone. This decision should also be endorsed by the county-based cities, markets, and municipalities'. In contrast to horizontal diffusion, vertical diffusion effects, which in these cases, stem from the county level, had not been expected.

All in all, there is sufficient empirical evidence that policy diffusion played a role in spreading cultivation bans at the local level in Germany. Not only did these bans diffuse horizontally from one local unit to another, as we assumed theoretically. While vertical diffusion might be due to hierarchic coordination by respective counties, learning is probably more important in the case of the horizontal diffusion of cultivation bans. Nevertheless, as this holds true for all factors that were analyzed here, it is difficult to assess how significant these diffusion effects were for cultivation bans in individual municipalities as in almost all cases various reasons were mentioned in the council resolutions.

\subsection{The Interdependencies between the Reasons for Banning GMO Cultivation}

The first part of the empirical analysis focused on the single frequencies of the statements given by municipalities. The second part considers the interdependencies between the reasons noted in the local council resolutions. Which combinations of reasons appear most frequently in these documents? 
Are there any patterns in the combinations of reasons why GMO cultivation in local spheres should be prohibited?

Figure 3 displays the interdependencies between the various statements made by the 131 municipalities that have been investigated. We excluded the category 'Character of provision' as it rather describes the nature of the policy measure than the reasons why certain policy measures are taken. The different categories of reasons are depicted as nodes. The bigger the size of the nodes, the more frequently municipalities mentioned the respective categories. The different categories are linked by edges. The darker the color and the bigger the size of an edge, the more frequently the two categories that are linked by the edge were mentioned together. In more detail, each edge represents the sum of joint mentions of two categories divided by the maximum number of theoretically possible joint mentions of the same two categories. For example, 'risks for the environment' was named by 46 municipalities and 'risks for human health' was named by 36 municipalities. Therefore, the number of cases where both categories could have been mentioned together is limited to 36 times. In fact, both of the categories were jointly named 27 times. Therefore, the ratio of both categories is 27 divided by 36 , equaling 0.75 or $75 \%$. The number of joint mentions is divided by the maximum number of theoretically possible joint mentions in order to control the different frequencies of mentioned categories.

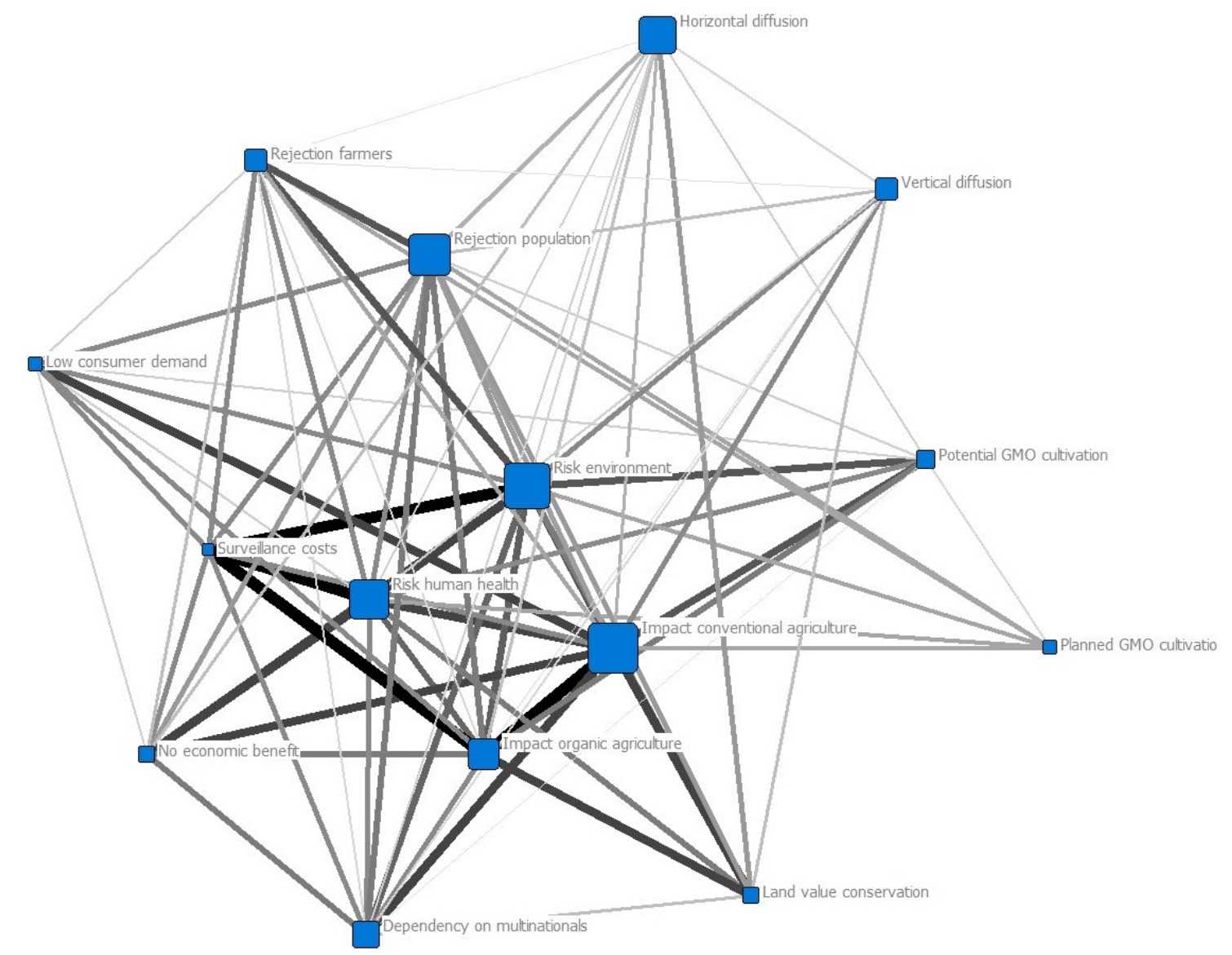

Figure 3. Interdependencies between reasons for banning genetically modified organisms (GMO) cultivation.

Computation of Cramer's $\mathrm{V}$ for the interdependencies between any two of the categories delivered similar results. We decided to use the method, as described above, for the reason of easier interpretation. All of the ratios can be found online in Table S2 of the Supplementary Materials. NetDraw [69] was used to create the graph.

When looking at the graph, it can be observed that a wide variety of combinations of different reasons for prohibiting GMO cultivation exists in communities' explanatory statements. Most of the nodes are linked by many other nodes. However, some reasons were combined many times, 
whereas others only occasionally or not at all. Turning to socio-economic reasons, we can see that these reasons are in general highly interconnected, which means that they are often mentioned together in one document. Most municipalities that referred to a negative impact on organic agriculture also mentioned a negative impact on conventional agriculture ( 24 of 25 possible combinations equaling $96 \%$ ). Communes worrying about a looming dependency of their farmers on multinationals referred to a negative impact of GMO cultivation on conventional agriculture in 13 of 21 cases (71\%).

The strongest interdependence can be observed between surveillance costs and the impact of GMOs on organic agriculture. In fact, communes mentioning the problem of surveillance costs always referred to the negative impacts on organic agriculture as well. However, only two communes mentioned surveillance costs, resulting in $100 \%$ of possible combinations. Therefore, this finding cannot be seen as representative. Finally, the potential problems of land value conservation were often mentioned in combination with a negative impact on conventional agriculture or organic agriculture (five of seven possible combinations equaling $71 \%$ in both cases).

The strong correlation between different sub-categories of socio-economic reasons is not surprising. It is indeed more interesting that these socio-economic reasons are very often stated in combination with the risks for human health or risks for the environment. Municipalities referring to a risk for the environment were also mentioning a negative impact on conventional agriculture in 31 of 46 cases $(67 \%)$. Similarly, communes referring to a negative impact on organic agriculture brought up risks for the environment in 16 of 25 cases ( $64 \%)$. The same pattern can be observed for socio-economic reasons and risks for human health: 26 of 36 municipalities mentioning risks for human health also referred to a negative impact on conventional agriculture (72\%) and 15 of 25 communes referring to organic agriculture also mentioned risks for human health $(60 \%)$.

When looking at the graph, it can be observed that these four categories are also located quite close to each other, forming a cluster of nodes. The position of nodes within the graph is determined by using a multi-dimensional-scaling technique (MDS). Multi-dimensional-scaling is a technique that is used (in network analysis) to assign locations to nodes in multi-dimensional spaces-in this case in a two-dimensional space-so that nodes that are 'more similar' are closer together. In this case, two nodes are 'similar' to the extent that they have similar shortest paths (geodesic distances) to all the other nodes [70].

Absolute distances between nodes cannot be interpreted meaningfully (a shorter distance between node $A$ and $B$ than between node $A$ and $C$ does not necessarily mean that there is a stronger interdependence between node $\mathrm{A}$ and $\mathrm{B}$ than between node $\mathrm{A}$ and $\mathrm{C})$. However, clusters of nodes can be interpreted. The four categories forming a cluster in this graph are interrelated to a higher degree than, for example, the categories environmental risk, horizontal diffusion, and vertical diffusion. Consequently, socio-economic aspects and environmental and health risks were not only mentioned most frequently, but they were also often mentioned in combination with each other. Finally, potential GMO cultivation was also combined frequently with a negative impact on conventional agriculture ( $66.6 \% ; 6$ out of 9 ) or on organic agriculture $(56 \% ; 5$ out of 9 ).

Examining political aspirations, there is some overlap between the rejection of GMOs by farmers and the rejection by the local population. Especially communes referring to farmers refusing GMOs often stated a negative stance of their general local population towards GMOs (10 of 15 communities). Contrary to the patterns that were observed before, rejection by farmers and negative impacts on organic or conventional agriculture were combined less frequently $(29 \%$ and $20 \%$, respectively). However, rejection by local citizens was more frequently mentioned in combination with a negative impact on organic agriculture (56\%) or with the dependency on multinationals $(57 \%)$. In general, the rejection by local citizens was mentioned in combination with most of the other reasons.

Regarding diffusion effects, horizontal and vertical diffusion processes seem to be mostly independent of each other (19\%). Horizontal diffusion is combined with many other categories. However, these combinations occurred rarely. Interestingly, eight of the sixteen municipalities referring to vertical diffusion also mentioned a negative impact through GMOs on conventional agriculture or 
risks for the environment (50\%). Possibly, these considerations might have played a central role on the county-level as well.

To conclude, the reasons for prohibiting GMO cultivation were combined in a wide variety. Nevertheless, some patterns in the combination of reasons can be observed. Most prominently, the two aspects socio-economic reasons and risks for the environment and human health were not only mentioned most frequently by communes but also oftentimes in combination.

\section{Concluding Remarks and Implications}

With this study, we examined patterns of GMO regulation on the local level, an issue that has received only scant attention in hitherto research yet. The study focused on three theoretical arguments to explain why municipalities might ban GMO cultivation in their territories and found general support for each of them when analyzing 131 German municipalities that took measures to prohibit the cultivation of GM crops on their arable land on a legal basis.

Functional motivations, especially socio-economic reasons and perceived risks for the environment or human health, turned out to be decisive for municipalities' decisions to impose cultivation bans. Although on the national level, Germany implemented strict rules for safeguarding 'co-existence' between GMO farming and conventional and organic agriculture, many municipalities had serious doubts about the feasibility of 'co-existence' and perceived possible 'contaminations' as severe threats, especially to organic farmers. Furthermore, communes feared that once GMOs were cultivated on a large scale, other farmers would have to adapt to GMO farming leading to a dependency on multinationals, an enhancement of industrial agriculture, and a replacement of traditional agricultural practice characterized by small-scale farming.

Municipalities also referred to risks for the environment and human health as reasons why GMO cultivation should be prohibited on their land. However, we could show that these risks are often mentioned in combination with socio-economic reasons. The impression prevails that mostly socio-economic aspects rather than perceived risks for the environment or local people's health induced municipalities to become active and impose cultivation bans. This observation corresponds with previous studies, which identified socio-economic concerns as well as perceived risks as key drivers of the low public and political support for GMOs in the EU [51,53,60,71].

Moreover, the results of this study support the argument that local policymakers seek credit for popular cultivation bans, and, therefore, respond to the resistance of local farmers or the local population against GMO cultivation due to their own political aspirations. This observation corresponds with findings of Hartung and Hörisch [8], who found that, on the German regional level, political parties as a whole, as well as politicians, recognize the credit-claiming possibilities due to the GMO issue, and, therefore, introduce popular regulations to boost their electoral success. However, policymakers might not only respond to their electorates; ideologic and ethical motives, concerns over socio-economic consequences, as well as over environmental or health risks, all represent possible personal reasons, which might motivate them to promote regulatory action.

Finally, municipalities implemented cultivation bans as a reaction to similar policies adopted beforehand by other municipalities or by units on higher political levels. While horizontal diffusion between municipalities can be explained by learning processes of actors in the recipient communes, vertical diffusion from higher political levels can be explained by hierarchic coordination.

The elaborate analysis of local council resolutions underpinned these conclusions with a number of reasons released by the municipalities to justify regulatory action. Overall, the study provides valuable insights into the various reasons as to why municipalities become active and impose bans on GMO cultivation in their respective areas. Motta [72] (p. 1370) stated that 'the social and environmental effects of the global expansion of biotechnology are mostly concentrated at the local level, in the rural and suburban communities that surround GM fields'. The study at hand demonstrated that GMO farming is a multi-dimensional issue at the local level: in local councils across Germany, disparate, 
but almost exclusively negatively biased views dominated on the (potential) effects of this farming practice, which in turn often triggered political decisions against GMO cultivation.

Municipalities' possibility to prohibit agricultural technologies on their leased land in combination with negatively biased views towards new technologies will possibly have negative implications for future agricultural innovations. Municipalities are free to include any exclusion clause in their lease contracts. Accordingly, municipalities can prohibit farmers from using any new technology on their leased land. The new breeding technique Crispr/Cas represents a current case. On 25 July 2018, the European Court of Justice ruled that new breeding techniques, such as Crispr/Cas, would fall into the scope of Directive 2001/18, which defines a GMO [73]. Consequently, this means that the local cultivation bans already in place, which apply to GM crops of all varieties, also apply to these newly modified crops. One has to bear in mind, however, that municipalities in most cases only own a share of the land on their territory.

The results of this study further emphasize the importance of examining the full complexity of agri-food systems [74]. German municipalities' rejection of GMOs reveals the problems of looking only at single effects, such as the increase of net income gains of farmers adopting GM crops. Instead, it is important to take a holistic view and analyze the interdependencies between agroecosystems and socio-economic systems in their full complexity in order to understand whether the introduction of a new technology, GMOs in this case, will be compatible with existing socio-economic systems, accepted by society, and de facto improve the agri-food systems' sustainability in the end.

The method of document analysis comes with the possible limitation that we do not encompass all the relevant reasons for regulatory action on GMOs on a local level because arguments for banning GMO cultivation might not have been written down in the council resolutions. Thus, the results of this study might leave some space for possible variations in the relative significance of the factors underlying local cultivation bans. One possibility for future research is to examine a small number of particularly interesting communes in case studies. In addition, an analysis of municipalities in which farmers grew GM crops or where a ban was proposed, but not implemented, would be insightful. Further studies could also build on this study and focus on the role of increasing local resilience or the importance of symbolism. By using expert interviews or surveys, more fine-grained data could be derived, which, in turn, could allow for producing more detailed knowledge about the relative significance of the various determinants of local GMO cultivation bans in specific cases. However, many local debates about GMOs took place more than a decade ago, making it thereby difficult to collect reliable data. Using these methods, therefore, comes with some problems.

Finally, the analysis of GMO regulatory activity at the local level could be expanded to other countries, where municipalities have possibilities to regulate this policy field. In this context further, interesting questions could be addressed as for example which legal possibilities municipalities have for doing so, to what extent they make use of these, whether units use informal arrangements to restrict GMO cultivation, and which factors trigger local regulatory action in these countries.

Supplementary Materials: The following are available online at http:/ / www.mdpi.com/2071-1050/10/10/3392/ s1, Table S1: List of municipalities with cultivation bans; Table S2: Interdependencies between reasons for banning GMO cultivation

Author Contributions: Conceptualization, U.H.; formal analysis, U.H. and S.S.; investigation, U.H.; writing, U.H. and S.S.; visualization, S.S.; supervision, Jale Tosun.

Funding: Ulrich Hartung is being funded by the German Federal Environmental Foundation.

Acknowledgments: This study benefited from valuable comments of the participants of the RNAi socio-economy (WG4) panel at the '1st COST/iPlanta Conference Creating a Plant RNAi Research Network' (COST Action CA15223) held on 15-17 February 2017 at the University Sapienza and CNR headquarters in Rome, Italy. Julian Erhard and Paul Thalmann deserve credit for valuable research assistance. We acknowledge financial support by Deutsche Forschungsgemeinschaft within the funding programme Open Access Publishing, by the Baden-Württemberg Ministry of Science, Research and the Arts and by Ruprecht-Karls-Universität Heidelberg.

Conflicts of Interest: The authors declare no conflict of interest. 


\section{References}

1. Brookes, G.; Barfoot, P. Environmental impacts of genetically modified (GM) crop use 1996-2015: Impacts on pesticide use and carbon emissions. GM Crop. Food 2017, 8, 117-147. [CrossRef] [PubMed]

2. Levidow, L.; Boschert, K. Coexistence or contradiction? GM crops versus alternative agricultures in Europe. Geoforum 2008, 39, 174-190. [CrossRef]

3. Zilberman, D.; Holland, T.; Trilnick, I. Agricultural GMOs-What we know and where scientists disagree. Sustainability 2018, 10, 1514. [CrossRef]

4. Potrykus, I. Unjustified regulation prevents use of GMO technology for public good. Trends Biotechnol. 2013, 31, 131-133. [CrossRef] [PubMed]

5. Tosun, J. Agricultural biotechnology in central and Eastern Europe: Determinants of cultivation bans. Sociol. Ruralis 2014, 54, 362-381. [CrossRef]

6. Dobbs, M. Attaining subsidiarity-based multilevel governance of genetically modified cultivation? J. Environ. Law 2016, 28, 245-273. [CrossRef]

7. Bodiguel, L.; Cardwell, M.; Garcia, A.C.; Viti, D. Coexistence of Genetically Modified, Conventional, and Organic Crops in the European Union: National Implementation. In The Regulation of Genetically Modified Organisms: Comparative Approaches; Bodiguel, L., Cardwell, M., Eds.; Oxford University Press: Oxford, UK, 2010.

8. Hartung, U.; Hörisch, F. Regulation vs Symbolic Policy-Making: Genetically Modified Organisms in the German States. Ger. Politics 2018, 27, 380-400. [CrossRef]

9. Hristova, V. Between Politics and Science: Accommodating National Diversity in GMO Regulation. In Balancing between Trade and Risk: Integrating Legal and Social Science Perspectives; van Asselt, M.B.A., Versluis, E., Vos, E., Eds.; Routledge: London, UK; New York, NY, USA, 2013; pp. 107-127.

10. Katzek, J. At the end of the day everything boils down to politics: The evolving of German policy toward GMO crops and the existing stagnation. GM Crops Food 2014, 5, 178-182. [CrossRef] [PubMed]

11. Seifert, F. Regional GM opposition as multilevel challenge? The case of Upper Austria. Tail. Biotechnol. 2006, 2,11-36.

12. Tosun, J.; Hartung, U. Decentralising competences in multi-level systems: Insights from the regulation of genetically modified organisms. West Eur. Politics 2018, 41, 803-823. [CrossRef]

13. Friedrich, B. Lokale und regionale Konflikte um Agro-Gentechnik. In Politiken der Naturgestaltung: Ländliche Entwicklung und Agro-Gentechnik zwischen Kritik und Vision; Gottschlich, D., Mölders, T., Eds.; Springer: Wiesbaden, Germany, 2017; pp. 153-169.

14. Wagner, J. Analyse der sozialen Konflikte um den Einsatz der Agro-Gentechnik im ländlichen Raum. In Agro-Gentechnik im ländlichen Raum: Potentiale, Konflikte, Perspektiven; Köstner, B., Vogt, M., van Saan-Klein, B., Eds.; Röll: Dettelbach, Germany, 2007; Volume 22, pp. 117-132.

15. Hoppichler, J.; Schermer, M. Gentechnikfreie Regionen als alternative Entwicklungsperspektive in benachteiligten Gebieten. In Agro-Gentechnik im ländlichen Raum: Potentiale, Konflikte, Perspektiven; Köstner, B., Vogt, M., van Saan-Klein, B., Eds.; Röll: Dettelbach, Germany, 2007; Volume 22.

16. Nischwitz, G.; Kuhlicke, C.; Bodenschatz, T.; Thießen, B.; Tittel, K. Sondierungsstudie Gentechnikfreie Regionen in Deutschland: Eine Sozioökonomische Analyse am Beispiel der Brandenburgischen Uckermark; Institut für ökologische Wirtschaftsforschung: Berlin, Germany, 2005. Available online: https://www.ioew.de/ publikation/sondierungsstudie_gentechnikfreie_regionen_in_deutschland/ (accessed on 21 September 2018).

17. Schermer, M.; Hoppichler, J. GMO and sustainable development in less favoured regions-The need for alternative paths of development. J. Clean. Prod. 2004, 12, 479-489. [CrossRef]

18. GMO-Free Regions. GMO-Free Communities in Germany. 2018. Available online: http:// www.gentechnikfreie-regionen.de/regionen-gemeinden/gentechnikfreie-kommunen.html (accessed on 21 September 2018).

19. Salvi, L. The EU Regulatory Framework on GMOs and the Shift of Powers towards Member States: An Easy Way Out of the Regulatory Impasse? Eur. Food Feed Law Rev. 2016, 11, 201-210.

20. Consmüller, N.; Beckmann, V.; Schleyer, C. The Role of Coordination and Cooperation in Early Adoption of GM Crops: The Case of Bt Maize in Brandenburg, Germany. AgBioForum 2009, 12, 47-59.

21. Cooper, A. Political Indigestion: Germany Confronts Genetically Modified Foods. Ger. Politics 2009, 18, 536-558. [CrossRef] 
22. Lieberman, S.; Gray, T. The so-called 'moratorium' on the licensing of new genetically modified (GM) products by the European Union 1998-2004: A study in ambiguity. Environ. Politics 2006, 15, 592-609. [CrossRef]

23. Federal Office of Consumer Protection and Food Safety. Location Register. 2018. Available online: http: / /apps2.bvl.bund.de/stareg_web / showflaechen.do (accessed on 21 September 2018).

24. Kuntz, M. Destruction of public and governmental experiments of GMO in Europe. GM Crop.s Food 2012, 3, 258-264. [CrossRef] [PubMed]

25. Council Directive of 23 April 1990 on the Deliberate Release into the Environment of Genetically Modified Organisms (90/220 /EEC). Available online: https:/ / eur-lex.europa.eu/legal-content/EN/TXT/PDF/?uri= CELEX:31990L0220\&from=en (accessed on 13 August 2018).

26. Boschert, K.; Gill, B. Germany's agri-biotechnology policy: Precaution for choice and alternatives. Sci. Public Policy 2005, 32, 285-292. [CrossRef]

27. Directive 2001/18/EC of the European Parliament and of the Council, of 12 March 2001 on the Deliberate Release into the Environment of Genetically Modified Organisms and Repealing Council Directive 90/220/EEC. Available online: https:/ / eur-lex.europa.eu/resource.html?uri=cellar:303dd4fa-07a8-4d2086a8-0baaf0518d22.0004.02/DOC_1\&format=PDF (accessed on 13 August 2018).

28. Regulation (EC) No 1830/2003 of the European Parliament and of the Council of 22 September 2003 Concerning the Traceability and Labelling of Genetically Modified Organisms and the Traceability of Food and Feed Products Produced from Genetically Modified Organisms and Amending Directive 2001/18/EC. Available online: https: / eur-lex.europa.eu/legal-content/EN/TXT/PDF/?uri=CELEX:32003R1830\&qid= 1534787387538\&from=EN (accessed on 13 August 2018).

29. European Commission. Guidelines for the Development of National Strategies and Best Practices to Ensure the Co-Existence of Genetically Modified Crops with Conventional and Organic Farming. Brussels, Belium, 2003. Available online: https:/ / ec.europa.eu/agriculture/publi/reports/coexistence2/guide_en. pdf (accessed on 21 September 2018).

30. European Commission. Commission Recommendation of 13 July 2010 on Guidelines for the Development of National Co-Existence Measures to Avoid the Unintended Presence of GMOs in Conventional and Organic Crops. Brussels, Belgium, 2010. Available online: https:/ / eur-lex.europa.eu/legal-content/EN/TXT/PDF/ ?uri=CELEX:32010H0722\&from=EN (accessed on 21 September 2018).

31. Weimer, M. Risk Regulation, GMO's, and the Challenges to Deliberation in EU Governance-Politicization and Scientification as Co-Producing Trends. Amsterdam Centre for European Law and Governance Working Paper Series; Amsterdam, The Netherlands, 2014. Available online: file:/ / C:/Users/Ulrich\%20Hartung/ Downloads/acelg-wp-2014-03-maria-weimer.pdf (accessed on 21 September 2018).

32. The European Coexistence Bureau. Documents. 2018. Available online: http://ecob.jrc.ec.europa.eu/ documents.html (accessed on 21 September 2018).

33. German Genetic Engineering Act. Available online: https://www.gesetze-im-internet.de/gentg/ BJNR110800990.html (accessed on 13 August 2018).

34. Verordnung über die gute Fachliche Praxis bei der Erzeugung Gentechnisch Veränderter Pflanzen (Gentechnik-Pflanzenerzeugungsverordnung-GenTPflEV). 2008. Available online: https:/ /www.gesetzeim-internet.de/gentpflev / BJNR065500008.html (accessed on 21 September 2018).

35. Venus, T.; Dillen, K.; Punt, M.; Wesseler, J. (Eds.) The role of farmers' costs of coexistence measures for planting Gm Maize in Germany. In Proceedings of the GMCC-13 Conference, Lisbon, Portugal, 12-15 November 2013.

36. Schenkelaars, P.; Wesseler, J. Farm-level GM Coexistence Policies in the EU: Context, Concepts and Developments. EuroChoices 2016, 15, 5-11. [CrossRef]

37. Schier, A. Feldzerstörungen in Deutschland: Bilanz 2006. MAIS 2007, 34, 48-50.

38. Wickson, F.; Wynne, B. Ethics of Science for Policy in the Environmental Governance of Biotechnology: MON810 Maize in Europe. Ethics Policy Environ. 2012, 15, 321-340. [CrossRef]

39. Ober, S. Zwischen Forschungsfreiheit und Anwendungsrisiko am Beispiel des Risikodiskurses um MON810. In Grüne Gentechnik: Zwischen Forschungsfreiheit und Anwendungsrisiko: Zu den Normativen Voraussetzungen der Forschungsfreiheit am Beispiel des Risikodiskurses um MON810, 1st ed.; Grimm, H., Schleissing, S., Eds.; Nomos Verlagsgesellschaft mbH \& Co., KG: Baden-Baden, Germany, 2012; pp. 275-290. 
40. Salz, J. BASF Stampft Genkartoffel Amflora ein. Wirtschaftswoche 2012. Available online: https:// www.wiwo.de/unternehmen/industrie/chemie-basf-stampft-genkartoffel-amflora-ein/6072750-all.html (accessed on 21 September 2018).

41. Paskalev, V. Can science tame politics: The collapse of the new GMO regime in the EU. Eur. J. Risk Regul. 2012, 3, 190-201. [CrossRef]

42. USDA Foreign Agricultural Service. Germany, Agricultural Biotechnology Annual. 2016. Available online: https://gain.fas.usda.gov/Recent\%20GAIN\%20Publications /Agricultural\%20Biotechnology\% 20Annual_Berlin_Germany_8-25-2017.pdf (accessed on 21 September 2018).

43. Directive (EU) 2015/412 of the European Parliament and of the Council, of 11 March 2015 Amending Directive 2001/18/EC as Regards the Possibility for the Member States to Restrict or Prohibit the Cultivation of Genetically Modified Organisms (GMOs) in Their Territory. Available online: https:/ / eur-lex.europa.eu/ legal-content/EN/TXT/PDF/?uri=CELEX:32015L0412\&from=EN (accessed on 13 August 2018).

44. Federal Ministry of Food and Agriculture. Entwurf eines Vierten Gesetzes zur Änderung des Gentechnikgesetzes. Available online: https://www.bmel.de/SharedDocs/Downloads/Landwirtschaft/ Pflanze/GrueneGentechnik/EntwurfAenderungGenTG_Kabinett.pdf?_blob=publicationFile (accessed on 20 February 2015).

45. Wehling, H.-G.; Kost, A. Kommunalpolitik in der Bundesrepublik Deutschland-Eine Einführung. In Kommunalpolitik in den Deutschen Ländern: Eine Einführung, 2nd ed.; Kost, A., Wehling, H.-G., Eds.; VS Verl. für Sozialwiss: Wiesbaden, Germany, 2010; pp. 7-18.

46. Holtkamp, L. Kommunale Konkordanz- und Konkurrenzdemokratie: Parteien und Bürgermeister in der Repräsentativen Demokratie; VS Verlag für Sozialwissenschaften: Wiesbaden, Germany, 2008.

47. Herrick, C.B. 'Cultures of GM': Discourses of risk and labelling of GMOs in the UK and EU. Area 2005, 37, 286-294. [CrossRef]

48. Herring, R.; Paarlberg, R. The Political Economy of Biotechnology. Annu. Rev. Resour. Econ. 2016, 8, 397-416. [CrossRef]

49. Klümper, W.; Qaim, M. A meta-analysis of the impacts of genetically modified crops. PLoS ONE 2014, 9, e111629. [CrossRef] [PubMed]

50. Regulation (EC) No 1829/2003 of the European Parliament and of the Council of 22 September 2003 on Genetically Modified Food and Feed (Text with EEA Relevance). Available online: https: / / eur-lex.europa. eu/legal-content/EN/TXT/PDF/?uri=CELEX:32003R1829\&qid=1534787473950\&from=EN (accessed on 13 August 2018).

51. Catacora-Vargas, G.; Binimelis, R.; Myhr, A.I.; Wynne, B. Socio-economic research on genetically modified crops: A study of the literature. Agric. Hum. Values 2018, 35, 489-513. [CrossRef]

52. Oehen, B.; Quiédeville, S. Socio-Economic Impacts of GMOs on European Agriculture. 2017. Available online: http:/ / orgprints.org/33084/1/SOCIO-ECONOMIC\%20IMPACTS\%20OF\%20GMOs.pdf (accessed on 13 August 2018).

53. Kathage, J.; Gómez-Barbero, M.; Rodríguez-Cerezo, E. Framework for Assessing the Socio-Economic Impacts of Bt Maize Cultivation: EUR 28129 EN; Publications Office of the European Union: Luxembourg, 2016. [CrossRef]

54. Müller, W.C.; Strøm, K. Policy, Office, or Votes?: How Political Parties in Western Europe Make Hard Decisions; Cambridge University Press: Cambridge, MA, USA, 1999.

55. Strøm, K. A behavioral theory of competitive political parties. Am. J. Political Sci. 1990, 34, 565-598. [CrossRef]

56. Skjæveland, A.; Serritzlew, S.; Blom-Hansen, J. Theories of coalition formation: An empirical test using data from Danish local government. Eur. J. Political Res. 2007, 46, 721-745. [CrossRef]

57. Malyska, A.; Bolla, R.; Twardowski, T. The Role of Public Opinion in Shaping Trajectories of Agricultural Biotechnology. Trends Biotechnol. 2016, 34, 530-534. [CrossRef] [PubMed]

58. Kurzer, P.; Cooper, A. What's for Dinner? Comp. Political Stud. 2007, 40, 1035-1058. [CrossRef]

59. Legge, J.S., Jr.; Durant, R.F. Public opinion, risk assessment, and biotechnology: Lessons from attitudes toward genetically modified foods in the European Union. Rev. Policy Res. 2010, 27, 59-76. [CrossRef]

60. Durant, R.F.; Legge, J.S. Public Opinion, Risk Perceptions, and Genetically Modified Food Regulatory Policy. Eur. Union Politics 2005, 6, 181-200. [CrossRef]

61. Wenzelburger, G.; Hörisch, F. Unpopular Social Policy Reform and Strategic Communication: An Introduction. J. Comp. Policy Anal. Res. Pract. 2016, 18, 113-121. [CrossRef] 
62. Gupta, C. Contested fields: An analysis of anti-GMO politics on Hawai'i Island. Agric. Hum. Values 2017, 35, 181-192. [CrossRef]

63. Shipan, C.R.; Volden, C. The mechanisms of policy diffusion. Am. J. Political Sci. 2008, 52, 840-857. [CrossRef]

64. Gilardi, F. Four Ways We Can Improve Policy Diffusion Research. State Politics Policy Q. 2016, 16, 8-21. [CrossRef]

65. Gilardi, F. Transnational diffusion: Norms, ideas, and policies. In Handbook of International Relations; Carlsnaes, W., Risse, T., Simmons, B.A., Eds.; Sage: Los Angeles, CA, USA, 2012; pp. 453-477.

66. Graham, E.R.; Shipan, C.R.; Volden, C. The Diffusion of Policy Diffusion Research in Political Science. Br. J. Political Sci. 2013, 43, 673-701. [CrossRef]

67. Bednar, J. The Political Science of Federalism. Annu. Rev. Law Soc. Sci. 2011, 7, 269-288. [CrossRef]

68. Mayring, P. Qualitative Content Analysis. 2000. Available online: http://www.qualitative-research.net/ index.php/fqs/article/view/1089/2384 (accessed on 13 August 2018).

69. Borgatti, S.P. NetDraw Software for Network Visualization; Analytic Technologies: Lexington, KY, USA, 2002; Volume 95.

70. Hanneman, R.A.; Riddle, M. Introduction to Social Network Methods. 2005. Available online: http: / / faculty.ucr.edu/ hanneman/ (accessed on 21 September 2018).

71. Frewer, L.J.; Miles, S.; Marsh, R. The Media and Genetically Modified Foods: Evidence in Support of Social Amplification of Risk. Risk Anal. 2002, 22, 701-711. [CrossRef] [PubMed]

72. Motta, R. Social disputes over GMOs: An overview. Sociol. Compass 2014, 8, 1360-1376. [CrossRef]

73. European Court of Justice. Organisms Obtained by Mutagenesis Are GMOs and Are, in Principle, Subject to the Obligations Laid Down by the GMO Directive; Press Release: Luxembourg, 2017. Available online: https: / curia.europa.eu/jcms/upload/docs/application/pdf/2018-07/cp180111en.pdf (accessed on 21 September 2018).

74. Giampietro, M. Multi-Scale Integrated Analysis of Agroecosystems; CRC Press: Boca Raton, FL, USA, 2004.

(C) 2018 by the authors. Licensee MDPI, Basel, Switzerland. This article is an open access article distributed under the terms and conditions of the Creative Commons Attribution (CC BY) license (http://creativecommons.org/licenses/by/4.0/). 